\title{
Occurrence of schistosomiasis in Divinópolis-MG based on study of schoolchildren and surveys of disease notification
}

\author{
Ocorrência de esquistossomose em Divinópolis-MG baseada em estudo \\ com escolares e em inquéritos de notificação da doença
}

\begin{abstract}
Karina Talita de Oliveira Santana ${ }^{1}$; Kayo Vieira Teodorak Pego ${ }^{2}$; Valeriana Valadares Pereira ${ }^{3}$; Larissa Parrela Rodrigues; Juliana Vitalina Ferreira ${ }^{4}$; Karla Nogueira de Oliveira ${ }^{4}$; Maria Jaciara Ferreira Trindade ${ }^{5}$; Hélio de Oliveira ${ }^{6}$; Eduardo Sergio da Silva'; Luciana Lara dos Santos ${ }^{8}$; Débora de Oliveira Lopes ${ }^{9}$
\end{abstract}

\begin{abstract}
Introduction: Schistosomiasis is a neglected chronic disease that affects mainly underdeveloped regions, including Brazil. Objective: To evaluate the distribution profile of the schistosomiasis in Divinópolis-MG. Material and methods: It is characterized as a descriptive and analytical epidemiological study. A parasitological study performed in schoolchildren of public municipal schools; simultaneously, a survey of schistosomiasis cases reported in the city between 2005 and 2011 years was performed with the Municipal Department of Health. Data related to the characteristics of the infection were observed, such as: affected areas, age, gender, and professional occupation. Results: This survey showed 33 cases of schistosomiasis in the city during this period, which the most of them (84.8\%) were between 20-59 years of age. The results of the study with the schoolchildren are in agreement with those obtained through the reporting forms, both indicating no occurrence of schistosomiasis in individuals between 6-14 years of age in Divinópolis. Conclusion: The absence of the disease in children and adolescents analyzed and the presence in adults is a strong evidence of exogenous contamination in the city, especially as a result of immigration or rural tourism, and possible changes in habits, related to risk factors.
\end{abstract}

Key words: schistosomiasis; control; epidemiology; prevalence; schoolchildren; kato-katz.

\section{INTRODUCTION}

Human schistosomiasis is a chronic debilitating helminth disease, with the highest death rate in the world caused by hematophagous parasites of the Schistosoma genus ${ }^{(2)}$. The major pathogenic species for humans are Schistosoma mansoni, Schistosoma japonicum, and Schistosoma baematobium. This disease is prevalent in tropical and subtropical areas, so it is present in several regions of South America, Africa, and Asia ${ }^{(23)}$. In Brazil, Schistosoma mansoni, the etiologic agent of schistosomiasis, is found mainly in the Northeast and in the State of Minas Gerais. It is estimated that 700 million people are at risk in 74 endemic countries, and more than 207 million people are infected ${ }^{(37)}$.

Schistosomiasis is one of the main neglected diseases worldwide. According to the Department of Health Surveillance of Ministry of Health, in 2008 there are approximately 121,602 infected people in Brazil, which 50,964 are from the State of Minas Gerais $^{(5)}$. The city of Divinópolis-MG is among the regions where disease is widespread, it is in the Center-West of Minas Gerais, with an estimated population of 213,016 people $^{(6,18)}$.

First submission on 13/04/14; last submission on 16/06/14; accepted for publication on $07 / 07 / 14$; published on 20/08/14

1. MSc in Genetics-Universidade Federal de Minas Gerais (UFMG).

2. Student of Medical-Universidade Federal de São João Del-Rei (UFSJ).

3. MSc in Health Sciences-UFS; laboratory technician at UFSJ; professor at Faculdade Pitágoras.

4. Pharmaceutical/biochemistry; health/biochemistry inspector-Municipal Department of Health Surveillance of Municipality of Divinópolis-MG.

5. Student of Biochemistry-UFSJ.

6. Student of Public Administration-UFSj; laboratory technician of Schistosomiasis Control Program (Programa de Controle da Esquistossomose) of Municipality of Divinópolis-MG.

7. PhD in Parasitology-UFMG; associate professor at UFSJ

8. PhD in Genetics-UFMG; associate professor at UFSJ.

9. PhD in Biochemistry and Immunology-UFMG; associate professor at UFSJ. 
S. mansoni has water as vehicle of transmission and uses mollusks of the genus Biomphalaria sp. as intermediate hosts. In Brazil, the main species of mollusks found are Biomphalaria tenagophila, Biomphalaria glabrata, and Biomphalaria straminea; the occurrence of the two first was reported at Divinópolis region ${ }^{(3,10)}$. The Schistosoma mansoni transmission occurs by active penetration of cercariae through the skin and mucosa that are released into the water by Biomphalaria snails. Often, the penetration occurs through feet and legs, since they are the more exposed areas of the body, when in contact with contaminated water ${ }^{(1,28)}$.

Clinically, schistosomiasis has two evolutionary phases: acute and chronic. The acute phase is mainly characterized by cercarial dermatitis and associated symptoms. The chronic phase of disease is classified according to the pathology involved, as intestinal, hepatic-intestinal, and hepatic-splenic. Clinical intestinal and hepatic-intestinal are usually asymptomatic. Individuals may progress to critical illness (hepatic-splenic), characterized by portal hypertension, severe hepatosplenomegaly, and development of collateral circulation due to hepatic fibrosis. This situation may evolve to an accumulation of fluid in the peritoneal cavity - ascites, with development of esophageal varices, which may rupture triggering bleeding that can lead the individual to death ${ }^{(1,28)}$.

Laboratory diagnosis of schistosomiasis is concluded mainly by the verification of Schistosoma eggs in patient's feces. The World Health Organization (WHO) recommends Kato-Katz method because it is an efficient, fast, and easy parasitological examination, and also is a quantitative and qualitative technique ${ }^{(21)}$. Additional tests such as polymerase chain reaction (PCR) and the serological tests have high sensitivity and would be useful, specially in areas of low prevalence of the disease, or in patients with low parasitemia and immunocompromised, therefore, these methods are unfeasible in routine due to their high costs ${ }^{(36)}$.

Currently, chemotherapy through Praziquantel, is considered the primary form of schistosomiasis control ${ }^{(11)}$. However, the constant reinfections, decrease in sensitivity to the drug seen in some strains, and difficulty in distribution suggest the need of a definitive intervention method to control of the disease ${ }^{(27)}$. The development of a vaccine in an essential component for sustainable control that may lead to eradication of schistosomiasis ${ }^{(26)}$. Constant reinfections also highlight the demand of implementing monitoring and surveillance programs, creating data that may constitute a powerful tool to define actions to combat diseases.
In 1975 was created in Brazil the Special Program for Control of Schistosomiasis (Programa Especial de Controle da Esquistossomose [PECE]), as schistosomiasis strategy control, which activities were primary directed to mass treatment of patients with oxamniquine. The control of vector mollusks was in small scale and irregular. Actions of sanitation, water supply, and health education were implemented sporadically ${ }^{(7,13)}$. PECE activities followed three operational phases: a) preparatory, in which the work area was defined and the initial parasitological survey was conducted; b) attack, in which control measures were carried out; c) surveillance, which included periodic evaluations and chemotherapy for new cases and/or not heal ${ }^{(13,25)}$. In 1980, PECE was no longer a special program; it was replaced by the Schistosomiasis Control Program (Programa de Controle da Esquistossomose [PCE]), a routine program of the Ministry of Health. After 1991, the parasitological surveys were at census, covering all ages, and chemotherapy now includes the positive individuals and their cohabitants ${ }^{(13)}$. After the decentralization of epidemiological and disease control, in 1999, by Ministry of Health, PCE became responsibility of municipalities. The implementation of schistosomiasis control activities by municipal authorities aimed at epidemiological delimitation, conducting stool examination census surveys, treatment of infected people, mollusks control, environmental sanitation, health education, epidemiological surveillance, and feeding of PCE information system (SISPCE) ${ }^{(27)}$. The Ministry of Health recommended that all these activities were incorporated to those developed by Health Community Workers Program (Programa de Agentes Comunitários de Saúde [PACS]) and Family Health Strategy (Estratégia de Saúde da Família $[\mathrm{ESF}])^{(4)}$.

In Brazil, as in other countries, a major change in schistosomiasis context occurred due to the control programs implemented since 1970s, however, despite such efforts, the disease continued to be widespread in the country, including the outbreak of disease ${ }^{(20,31)}$.

\section{OBJECTIVE}

To conduct a parasitological survey on schistosomiasis in schoolchildren between 6-14 years of age in the microregion of Divinópolis, Minas Gerais, during the period of 2010-2012 and, also, to conduct an epidemiological survey of the disease, according to the notifications at the Municipal Department of Health of Divinópolis (SEMUSA), related to the period 2005-2011. Data here created and analyzed aim to develop the schistosomiasis profile in the city of Divinópolis-MG. 


\section{MATERIAL AND METHODS}

The project is part of the Education Program at Work for Health-Health Surveillance (Programa de Educação pelo Trabalho para Saúde-Vigilância em Saúde-PET-Saúde/VS) conducted by the Ministry of Health, Universidade Federal de São João Del-Rei (UFSJ-MG) and by the Municipal Health Department of Divinópolis-MG. It is characterized as an analytical and descriptive epidemiological study, its casuistic are the results of parasitological examinations obtained by Kato-Katz method ${ }^{(19)}$ from schoolchildren of the microregion, as well as the notifications of schistosomiasis cases to the SEMUSA, in the city of Divinópolis-MG, in the period 20052011, through the schistosomiasis notifications forms query available at SEMUSA. This study was approved by the Research Ethics Committee of Fundação Educacional de Divinópolis (FUNEDI), protocol number 56/2009.

The territory of the municipality of Divinópolis is $708 \mathrm{~km}^{2}$, population of 213,016 people and population density is 300.82 people per square kilometer. Population is divided in 205,516 people living in urban area and 5,500 in rural area. Both Para and Itapecerica rivers flood the region, so that the latter passes through three cities and cuts Divinópolis in an extension of $29 \mathrm{~km}^{(18,33)}$. The city has a sewage collection system that serves about $81.4 \%$ of the population. The sewage is untreated, and the treated water supply covers $95,4 \%$ of the population. In addition, socioeconomic conditions also affect the incidence of poverty in $19,1 \%$ of people ${ }^{(18)}$

The target population of the study is schoolchildren between 6-14 years of age, of both genders, enrolled and frequent in public elementary schools of Divinópolis-MG. The city was divided by the Municipal City Hall in 11 planning regions, which takes into account the location per area and perimeter, they are: central, southeast, northeast, northwest, southwest, far northeast, west, far southwest, far northwest, northwest rural area, and southwest rural area. From 36 existing schools one was randomly selected for each region, representing all areas of the city. Thus, 11 public schools were contemplated.

Initially it was held contact with board members of the participating schools to present the Project, and subsequently, we meet those responsible for the schoolchildren, they received information booklets on schistosomiasis and guidelines on health education, emphasizing the cycle and progression of the disease. Those who joined the study signed an Informed Consent and filled a socioeconomic questionnaire.

To perform the parasitological test, all participating students received guidance regarding the collection that must be performed in a stool collection container preservative-free, properly identified.
Samples were collected in schools, properly packed and sent for processing at the Laboratory of Parasitology of UFSJ.

The samples were processed according to Kato-Katz method, using the helm-TEST ${ }^{\circledR}$ kit. A fraction of each sample was removed, placed on filter paper, and squeezed with a spatula on a sieve which helminth eggs and smaller debris pass through. Then, the samples that passed to the top of the sieve were collected, and with a spatula were transferred to the orifice of a plastic plate that was placed over a glass slide. The plastic plate was withdrawn and 42 milligrams of faeces remained on the glass slide. The material was covered with a lamina of cellophane paper, soaked in malachite green, and compressed, creating a well distribute sample. The slides remained at least sixty minutes drying in shade prior readings. Two slides were prepared for each sample, and were analyzed under microscopy using $10 \times$ and/or $40 \times$ objectives by four properly trained individuals.

Concurrently with this phase, we analyzed the notifications forms from the municipal passive surveillance, i.e., the data refer to those individuals who sought health services and had the diagnosis of schistosomiasis. In these records we collected information regarding gender, race, age, profession, the probable location of contamination, water collection identified as the site of infestation, and the treatment chosen/used. The data from this analysis were compared to the study in the schools.

\section{RESULTS}

It was analyzed 634 faecal samples from students, which $47.6 \%$ were males and $52.4 \%$ females. The age range of $6-8$ years accounted for $50.9 \%$ of total students, followed by $37.4 \%$ of $9-11$ years, and $11.7 \%$ of $12-14$ years. The family income of most of participating students (61\%) ranged between one and three minimum wages, for $11.7 \%$ of respondent, the family income was less than one minimum wage, and $27.3 \%$ had income higher than three minimum wages.

According to sanitary conditions (Table 1), which the students were subjected in the familiar environment, $85.2 \%$ had treated water, contrasting with $14.8 \%$ who did not have. Regarding the stool destination, $68.6 \%$ of housing had sewerage system services, $31.2 \%$ used septic tanks, and $0.2 \%$ had open sewage system. Toilet was present inside $97.3 \%$ houses, and $98.7 \%$ had water-flushed toilet.

After students performing Kato-Katz examination, there were no positive records for schistosomiasis. Eggs of other parasites were identified in the analysis, such as Ascaris lumbricoides, 
TABLE 1 - Sanitary conditions of the families of the students from public elementary schools in the city of Divinópolis-MG

\begin{tabular}{|c|c|c|}
\hline Sanitary conditions & $n$ & $\%$ \\
\hline \multicolumn{3}{|l|}{ Time living in the residence } \\
\hline Years & 533 & 84.1 \\
\hline Months or days & 101 & 15.9 \\
\hline \multicolumn{3}{|l|}{ Source of drinking water } \\
\hline Treated & 540 & 85.2 \\
\hline Untreated & 94 & 14.8 \\
\hline \multicolumn{3}{|l|}{ Type of housing } \\
\hline Masonry & 614 & 96.8 \\
\hline Adobe & 15 & 2.4 \\
\hline Wattle and daub/ improvised & 5 & 0.8 \\
\hline \multicolumn{3}{|l|}{ Type of home flooring } \\
\hline Ceramic/wood/stone/carpet & 543 & 85.6 \\
\hline Cement & 89 & 14.1 \\
\hline Beaten earth & 2 & 0.3 \\
\hline \multicolumn{3}{|l|}{ Existence of bathroom } \\
\hline One or more indoors & 617 & 97.3 \\
\hline Outside the home & 17 & 2.7 \\
\hline \multicolumn{3}{|c|}{ Sanitary facilities characteristics } \\
\hline With water discharge & 626 & 98.7 \\
\hline Without water discharge & 5 & 0.8 \\
\hline Septic tanks & 3 & 0.5 \\
\hline \multicolumn{3}{|l|}{ Destination of waste (stool) } \\
\hline Sewage system & 435 & 68.6 \\
\hline Septic tanks & 198 & 31.2 \\
\hline Open sewage & 1 & 0.2 \\
\hline \multicolumn{3}{|l|}{ Garbage disposal } \\
\hline Public collection system & 581 & 91.6 \\
\hline Burned/buried/other & 53 & 8.7 \\
\hline
\end{tabular}

Trichuris trichiura, hookworm, and Enterobius vermicularis (data not shown). Those with positive results were referred to the Health Centers or Family Health Program (Programa de Saúde da Familia) nearest to their residences, according to established partnerships.

The survey of notification data from 2005-2011, with records provided by SEMUSA, showed 33 cases of schistosomiasis in the studied period, and in 2010 occurred the highest number of notifications, 14 positives, followed by 2011 with nine cases (Figure).

Regarding gender, the highest frequency of schistosomiasis occurred in men $78.8 \%$ (26/33) and only 21.2\% (7/33) were notified in women. Regarding the age, infected individuals are mostly in the age group between 20-59 years (84.8\%), no records of the disease were found in children or adolescents under 15 years of age in the studied period (Table 2).

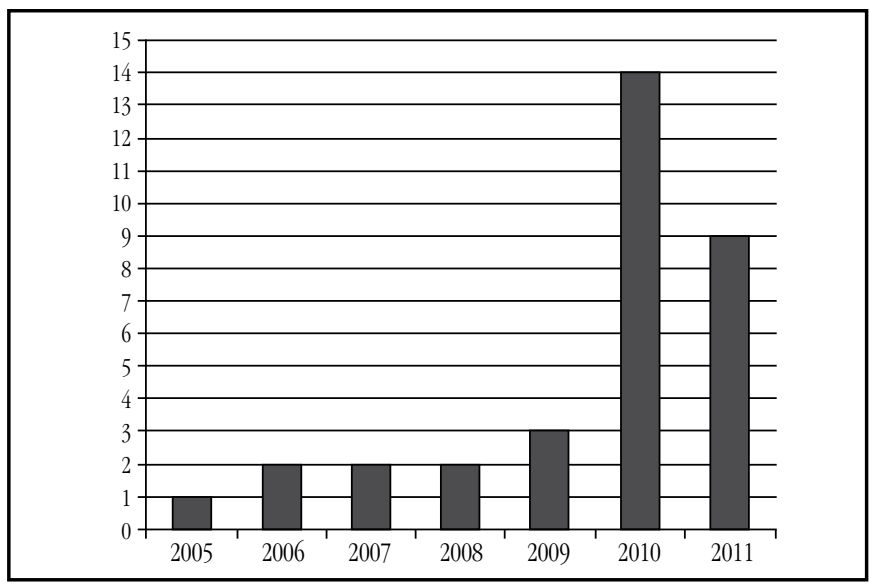

FIGURA - Schistosomiasis cases reported annually in the city of Divinópolis-MG in the period 2005-2011 (SEMUSA)

TABLE 2 - Number of schistosomiasis cases reported annually according to age group in the city of Divinópolis-MG in the period 2005-2011

\begin{tabular}{ccccccccc}
\hline & \multicolumn{9}{c}{ Age groups (years) } \\
\hline $\begin{array}{c}\text { Year of } \\
\text { notification }\end{array}$ & $0-19$ & $20-59$ & 60 or older & \multicolumn{2}{c}{ Total } \\
\hline 2005 & 0 & 0 & 1 & 3.6 & 0 & 0 & 1 & 3.0 \\
2006 & 0 & 0 & 2 & 7.1 & 0 & 0 & 2 & 6.1 \\
2007 & 0 & 0 & 1 & 3.6 & 1 & 33.3 & 2 & 6.1 \\
2008 & 0 & 0 & 2 & 7.1 & 0 & 0 & 2 & 6.1 \\
2009 & 0 & 0 & 2 & 7.1 & 1 & 33.3 & 3 & 9.1 \\
2010 & 0 & 0 & 14 & 50.0 & 0 & 0 & 14 & 42.4 \\
2011 & 2 & 100 & 6 & 21.5 & 1 & 33.3 & 9 & 27.2 \\
Total & 2 & 6.1 & 28 & 84.8 & 3 & 9.1 & 33 & 100 \\
\hline
\end{tabular}

Source: Municipal Health Department of Divinópolis-MG.

The distribution of individuals infected by schistosomiasis in rural and urban areas of Divinópolis-MG in the period 20052011 shows that most of the infected individuals (24/33) live in urban area. Of all cases notified in Divinópolis, 12 (36.4\%) are indigenous, 12 (36.4\%) are foreign, and nine (27.3\%) individuals did not known or did not declare where the contamination occurred.

All non-indigenous individuals mentioned locations in the State of Minas Gerais as likely sources of infection: the cities of São João da Ponte, Pai Pedro, Bom Despacho, Teófilo Otoni, Nova Serrana, Betim, Joaima, and Malacacheta. Most cases were treated with Praziquantel, and only two individuals used 0xamniquine. 
The professional occupation of individuals infected with schistosomiasis was investigated in order to assess this association. Among the 33 infected, nine work as houseman, farmer, and e retreatants, which are likely to be related to risk factors due to contact with any sources of contaminated water.

\section{DISCUSSION}

Schistosomiasis is a disease that has a complex epidemiological profile with several causal factors and broad geographic distribution $^{(38)}$. The socioeconomic and sanitary conditions of the population are relevant for schistosomiasis; low income, poor housing conditions, and locations without basic sanitation make the families more vulnerable to infection ${ }^{(14,22,29,30)}$. These factors are crucial in the transmission of schistosomiasis and other parasitic diseases. Therefore, descriptive analysis of the sanitary conditions of the families of the students contribute to point ways to target preventive measures for schistosomiasis, as well as Vasconcelos et al. studies ${ }^{(35)}$.

In this study, we observed that despite the Divinópolis microregion being classified as endemic for the disease, the parasitological examinations of surveyed students indicate absence of infected individuals. These data are consistent with the results obtained in epidemiological study in the period 2005-2011 in the city of Divinópolis, which also did not reported the existence of individuals of the same age group with the disease.

The absence of positive cases in the evaluated schoolchildren is likely due to children and adolescents behavioral changes, which do not use river and streams for leisure purposes so often. This fact is reassured by studies that show an increase in sedentary lifestyle among children and adolescents ${ }^{(17)}$, due to the long time spent on virtual activities, rather than performing physical effort activities $^{(32,34)}$. The fact that most cases of notification are related to alien infections may also contribute to justify the absence of infected children, since this age group is not significantly included in major population movements, as the adult population. It is important to mention that there is contamination in local water resources, as observed in Itapecerica River, which crosses the city receiving untreated sewage.

When evaluating the student groups, we found other parasites; however, no cases of multiparasitism were identified. These findings may have their indices increased if other diagnostic methods that have greater specificity in the identification of other helminths and protozoa were adopted, for example, the Hoffmann, Pons and Janer method ${ }^{(16)}$.
According to SEMUSA data, 33 cases of schistosomiasis were found, and most of them were notified in the period 2010-2011. This significant increase in number of notifications may be due to rather underreporting in the previous years, besides the fact that before 2010 only the severe cases were recorded. However, it should be noted that according to Article $3^{\circ}$ of the Ministerial Order $n^{\circ} 104$ of January $25^{\text {th }}$ of 2011 all cases of severe and chronic forms of schistosomiasis were then recorded in the National Disease Notification System (Sistema de Informação de Agravos de Notificação [SINAN]).

The number of me infected by schistosomiasis (78.8\%) is greater than the number of women (21.2\%), confirming Gomes et al. studies $^{(15)}$, in which men were the individuals most affected by schistosomiasis. This result raises the hypothesis that the pattern of exposure to contaminated water varies according to gender, likely reflecting the professional activities differentiated between men and women, and also on practices related to recreation.

The age range of 20-59 years of infected individuals belongs to the part of the economically active population. There were no reports in individuals under 18 or over 62 years. The occurrence of the disease more frequently in adults also corroborates the Vasconcelos et al. findings ${ }^{(35)}$.

In this study, we noticed a significant number of infected individuals in urban area, with 24 positive cases, in contrast with the occurrence of nine cases of schistosomiasis in rural area. the spread of the disease to urban areas may occur due to the practice of rural tourism, responsible for the occasional appearance of severe acute schistosomiasis cases ${ }^{(12)}$. There is a growing interest in rural properties for leisure and recreation purpose by people from urban areas. These rural properties, mostly, do not have basic sanitation infrastructure, which creates an impact on the environment and enables the transmission of schistosomiasis and other diseases associated with lack of basic sanitation. Another relevant factor in the migration of infected people, specially to the peripheral areas of large urban centers in the country ${ }^{(8,9,24)}$. This situation leads also to the creation of further outbreaks of schistosomiasis in non-endemic areas ${ }^{(12)}$.

The factors related to population displacement, either the rural tourism or migratory movements both also explain the number of non-indigenous cases in a particular region. This is verified in the 12 positive cases of this study. However, to clearly determine the factors that contribute to the distribution of schistosomiasis in the city, it would be required further specific study for this purpose, considering the peculiarity of schistosomiasis in the region, which includes the absence of positive records of disease currently affecting children and adolescents' population. 
It should be noticed that epidemiological surveys are of great importance in public health policies, because they enable the planning and directing actions. Given the historical records of the disease in Divinópolis, studies as this paper are relevant to delineate the current profile of schistosomiasis in the region.

\section{CONCLUSION}

Schistosomiasis is a disease that has the transmission associated with several factors. The absence of positive cases showed in students' parasitological study restated by schistosomiasis epidemiological survey in the city of Divinópolis, both reassure that the age group 6-14 years is not within the profile. However, after the same survey in the period 2005-2011, we noticed that a new profile of the disease is being outlined in the city. The facts presented here suggest that exogenous causes, such as migration and rural tourism may also be important factors in the spread of that disease.
A possible approach to new epidemiological studies in the region would be the use of more sensitive tests, such as serological or PCR methodologies that allow a more accurate identification of the number of infected people in regions with low or medium prevalence. It is important to emphasize the role of surveillance in preventing and combating diseases, as the schistosomiasis in urban areas also, since, according to data presented here, this disease may change profile from rural area affecting poor populations to affect other portions of the population.

\section{THANKS}

Fundação de Amparo à Pesquisa do Estado de Minas Gerais (FAPEMIG), Conselho Nacional de Desenvolvimento Científico e Tecnológico (CNPq), Ministry of Health (PET-Saúde), and Ministry of Education (MEC).

\section{RESUMO}

Introdução: A esquistossomose é uma doença crônica negligenciada, que afeta principalmente regiões subdesenvolvidas, incluindo o Brasil. Objetivo: Avaliar o perfil de distribuição da esquistossomose na região de Divinópolis-MG. Material e métodos: Caracteriza-se como um estudo epidemiológico analítico e descritivo. Foi realizado um estudo parasitológico em escolares da rede pública municipal e, concomitantemente, realizou-se também um levantamento dos casos notificados da doença no município entre 2005 e 2011, junto à Secretaria Municipal de Saúde. Foram verificados dados relacionados com as características da infecção, como regiōes afetadas, faixa etária, gênero e ocupação profissional. Resultados: O levantamento apontou 33 casos de esquistossomose no município neste período, sendo a maior parte deles (84,8\%) na faixa etária de 20 a 59 anos. Os resultados do estudo com os escolares estão em concordância com os obtidos por meio das fichas de notificação, ambos indicando a não ocorrência de esquistossomose em indivíduos de 6 a 14 anos em Divinópolis. Conclusão: A ausência da doença nas crianças enos adolescentes analisados e a presença em adultos sugerem forte evidência de contaminação exógena no município, especialmente fruto de imigração ou turismo rural, além de possíveis mudanças de bábitos, relacionados com os fatores de risco.

Unitermos: esquistossomose; controle; epidemiologia; prevalência; escolares; Kato-Katz.

\section{REFERENCES}

1. BARSOUM, R. S.; ESMAT, G.; EL-BAZ, T. Human schistosomiasis: clinical perspective: review. J Advanc Res, v. 4, p. 433-44, 2013.

2. BETHONY,J. M. et al. Can schistosomiasis really be consigned to history without a vaccine. Rev Vaccine, v. 26, p. 3373-6, 2008.

3. BRASIL. MINISTÉRIO DA SAÚDE (MS). Secretaria de Vigilância em Saúde. Departamento de Vigilância Epidemiológica. Surveillance and Control of Mollusks with Epidemiological Importance: technical directives: Schistosomiasis Control and Surveillance Program. Brasília: Ministério da Saúde, 2008.

4. BRASIL. MINISTÉRIO DA SAÚDE. Secretaria de atenção à Saúde. Departamento de atenção à saúde. Cadernos de atenção básica $n^{0}$ 21-Vigilância em saúde: Dengue, Esquistossomose, Hanseníase, Malária, Tracoma e Tuberculose. Brasília: Ministério da Saúde, 2008.

5. BRASIL. MINISTÉRIO DA SAÚDE (MS). DATASUS: Tecnologia da Informação a Serviço do SUS. População Residente - Minas Gerais. Ministério da Saúde, 2010. 
6. BRASIL. MINISTÉRIO DA SAÚDE (MS). Secretaria de Vigilância em Saúde. Departamento de Vigilância Epidemiológica. Casos confirmados de Esquistossomose 1995 a 2011. Grandes Regiões e Unidades Federadas, Brasil, 2011.

7. CAMARGO, S. The role of chemotherapy in special program for control of schistosomiasis. Rev Inst Med Trop São Paulo, v. 22, p. 98-104, 1980.

8. CARMO, E. H. et al. Esquistossomose mansônica no estado da Bahia, Brasil: tendências históricas e medidas de controle. Cad Saúde Pública, v. 10, p. 425-39, 1994.

9. CARVALHO, 0. S. et al. Re-evaluation of schistosomiasis mansoni in Minas Gerais, Brazil - II. Alto Parnaíba mesoregion. Mem Inst Oswaldo Cruz, v. 92, p.141-42, 1997.

10. CARVALHO, O. S. et al. The Estrada Real project and endemic diseases: the case of schistosomiasis, geoprocessing and tourism. Mem Inst Oswaldo Cruz, v. 105, p. 532-6, 2010.

11. DRUMMOND, S. C. et al. Schistosomiasis control program in the state of Minas Gerais in Brazil. Mem Inst Oswaldo Cruz, v. 105, p. 519-23, 2010 .

12. ENK, M. J. et al. Rural tourism: a risk factor for schistosomiasis transmission in Brazil. Mem Inst Oswaldo Cruz, v. 105, p. 537-40, 2010.

13. FAVRE, T. C. et al. Avaliação das ações de controle da esquistossomose implementadas entre 1977 e 1996 na área endêmica de Pernambuco, Brasil. Rev Soc Bras Med Trop, v. 34, p. 569-76, 2001.

14. GAZZINELLI, A. et al. Socioeconomic determinants of schistosomiasis in a poor rural area in Brazil. Running short title: socioeconomic determinants of schistosomiasis in Brazil.Acta Trop, v. 99, p. 260-71, 2006.

15. GOMES, E. C. S. et al. Risk analysis for occurrences of schistosomiasis in the coastal area of Porto de Galinhas, Pernambuco, Brazil. BMC Infect Dis, v. 14, n. 101, p. 1-12, 2014.

16. HOFFMAN, W. A.; PONS, J. A.; JANER, J. L. The sedimentationconcentration method in schistosomiasis mansoni. Puerto Rico J Pub Health Trop Med, v. 9, p. 281-98, 1934.

17. HONORATO, A. S. et al. Perfis antropométrico, lipídico e glicêmico em adolescentes de uma instituição filantrópica no noroeste do Paraná.J Bras Patol Med Lab, v. 46, p. 7-15, 2010.

18. INSTITUTO BRASILEIRO DE GEOGRAFIA E ESTATÍSTICA (IBGE). Sinopse do Censo Demográfico 2010 - Minas Gerais. Available at: < http:// www.ibge.gov.br/cidadesat/topwindow.htm?1>. Accessed on: $2011 \mathrm{Jul}, 10$.

19. KATZ, N.; CHAVES, A.; PELLEGRINO, J. A simple device for quantitative stool thick smear technique in schistosomiasis mansoni. Rev Inst Med Trop São Paulo, v. 14, p. 397-400, 1972.

20. KATZ, N. Schistosomiasis control in Brazil. Mem Inst Oswald Cruz, v. 93, p. 33-5, 1998.

21. KATZ, N. et al. Esquistossomose, xistosa, barriga d'água. Cienc Cult São Paulo, v. 55, p. 38-43, 2003.
22. KING, C. H. Parasites and poverty: the case of schistosomiasis. Acta Trop, v. 113, p. 95-104, 2010.

23. KING, C. H. et al. Utility of repeated praziquantel dosing in the treatment of schistosomiasis in high-risk communities in Africa: a systematic review. PLoS Negl Trop Dis, v. 5, p. e1321, 2011.

24. KLOOS, H. et al. Socioeconomic studies of schistosomiasis in Brazil: a review. Acta Trop, v. 108, p. 194-201, 2008.

25. MACHADO, P. A. Painel programa especial de controle de esquistossomose. Brasília: Ministério da Saúde, 1977.

26. MCMANUS, D. P. et al. Current status of vaccines for schistosomiasis. Clin Microbiol Rev, v. 21, p. 225-42, 2008.

27. MELMAN, S. D. et al. Reduced susceptibility to praziquantel among naturally occurring Kenyan isolates of Schistosoma mansoni. PLoS Negl Trop Dis, v. 3, p. e504, 2009.

28. MELO, A. L.; COELHO, P. M. Z. Schistosoma mansoni e a aoença. In: NEVES, D. P. Parasitologia bumana. 12. ed. São Paulo: Atheneu, 2011. Cap. 22; p. 209-30.

29. MUHUMUZA, S. et al. Association between socio economic status and schistosomiasis infection in Jinja District, Uganda. Trop Med and Int Health, v. 14, p. 612-9, 2009.

30. MWANGA, J. R. et al. Dynamics of people's socio-economic status in the face of schistosomiasis control interventions in Ukerewe district, Tanzania. Acta Trop, v.128, p. 399-406, 2013.

31. RABELLO, A. et al. Progress towards the detection of schistosomiasis. Geneva: special programme for research and training in tropical diseases. World Health Organization, 2005.

32. RIVERA, I. R. et al. Physical inactivity, TV-watching hours and body composition in children and adolescents. Arq Bras Card, v. 95, p. 159-65, 2010 .

33. SECRETARIA DE PLANEJAMENTO DE MINAS GERAIS. Quadro geral de dados fisiográficos. Prefeitura de Divinópolis-MG, 2012.

34. SICHIERI, R.; SOUZA, R. A. Estratégias para prevenção da obesidade em crianças e adolescentes. Cad Saúde Pública, v. 24, Sup 2, p. 209-22, 2008.

35. VASCONCELOS, C. H. et al. Avaliação de medidas de controle da esquistossomose mansoni no Município de Sabará, Minas Gerais, Brasil, 1980-2007. Cad Saúde Pública, v. 25, p. 997-1006, 2009.

36. VRANJAC, A. Manual de vigilância epidemiológica e controle da esquistossomose. Normas e instruções. Doenças transmitidas por água e alimentos. Secretaria de Estado da Saúde. São Paulo, 2007.

37. WORLD HEALTH ORGANIZATION (WHO). Schistosomiasis. Fact sheet $n^{0} 115$, WHO Media centre, 2010.

38. WORLD HEALTH ORGANIZATION (WHO). Schistosomiais Control. Geneve: WHO. Technical Series, 728, 1985.

\section{MAILING ADDRESS}

Débora de Oliveira Lopes

Av. Sebastião Gonçalves Coelho, 400; Chanadour; CEP: 35501-296; Divinópolis-MG, Brazil; e-mail: debora@ufsj.edu.br. 